\title{
The Conservative parliamentary party
}

\author{
Philip Cowley and Mark Stuart ${ }^{1}$
}

When the Conservative Party gathered for its first party conference since the 1997 general election, they came to bury the parliamentary party, not to praise it. The preceding five years had seen the party lose its (long-enjoyed) reputation for unity, and the blame for this was laid largely at the feet of the party's parliamentarians. ${ }^{2}$ As Peter Riddell noted in The Times, 'speaker after speaker was loudly cheered whenever they criticised the parliamentary party and its divisions'. ${ }^{3}$ It was an argument with which both the outgoing and incoming Prime Ministers were in agreement. Just before the 1997 general election, John Major confessed to his biographer that 'I love my party in the country, but I do not love my parliamentary party'; he was later to claim that 'divided views - expressed without restraint - in the parliamentary party made our position impossible'. And in his first address to the massed ranks of the new parliamentary Labour Party after the election Tony Blair drew attention to the state of the Conservative Party:

Look at the Tory Party. Pause. Reflect. Then vow never to emulate. Day after day, when in government they had MPs out there, behaving with the indiscipline and thoughtlessness that was reminiscent of us in the early 80 s. Where are they now, those great rebels?

His answer was simple: not in Parliament. 'When the walls came crashing down beneath the tidal wave of change, there was no discrimination between those Tory MPs. They were all swept away, rebels and loyalists alike.' ${ }^{5}$

They certainly were. The Conservative parliamentary party elected in 1997 comprised just $165 \mathrm{MPs}$, lower than at any time since $1906 .{ }^{6}$ Moreover, a combination of a higher than usual number of pre-election retirements (seventy-two Conservative MPs had stood down before the election), together with the savage effects of their electoral performance (which accounted, inter alia, for a record seven Cabinet ministers), meant that this 165 included few experienced parliamentarians. One defeated Conservative MP, David Sumberg, commented that he did not mind losing his seat 'because he would no longer be able to recognise anyone in the Commons'.7 A full quarter of the 
parliamentary party was new; just thirty-six had experience of politics in Opposition. ${ }^{8}$ Facing the new Labour government, therefore, was one of the smallest and least-experienced groups of parliamentarians ever to constitute Her Majesty's Official Opposition.

\section{The choice of Hague}

Their first main task was to choose John Major's successor. It was the last time the Conservative parliamentary party would be solely responsible for deciding the leadership of the party. It was a power they had gained in 1965 but one of William Hague's first acts as leader was to amend the leadership rules. ${ }^{9}$ When his replacement came to be chosen (see below), the party's MPs no longer enjoyed the ultimate power of selection.

But why did the party's MPs choose Hague? Just months before, the then Conservative MP and diarist, Gyles Brandreth, had noted the response in the Members' tea room to the idea of Hague as party leader: 'please, you cannot be serious!' 10 As well as the absence of other potential candidates, such as Michael Portillo (who had lost his seat in Enfield Southgate, and was thus de facto, if not de jure, ineligible) and Michael Heseltine (whose attack of angina ruled him out of the race), two other main factors enabled Hague to take the leadership.

First, the right of the party - especially the Euro-sceptic right - shot themselves in the foot. Like many other Conservative leadership contests, there was a clear ideological division between the source of the candidates' support. ${ }^{11}$ Kenneth Clarke's support came mainly from pro-European Conservative MPs. Hague's support came mainly from MPs in the centre of the party. But three candidates - John Redwood, Peter Lilley and Michael Howard - drew their support predominantly from the Euro-sceptic right of the party, splitting the sceptic vote into three, and ensuring that they came third, fourth and fifth respectively. ${ }^{12}$ But between them they had amassed over seventy votes, enough to have put one of them in first place, at least in the first round of the contest. Had there been just one candidate from the right, therefore, it is entirely plausible that Hague would have ended up in third place in the first round of the contest and been forced to withdraw.

The second main cause of Hague's success was that he was the least unpopular of the candidates. Given the number of candidates standing for election, there were almost bound to be multiple rounds of voting in the contest - in the event there were three - and, as a result, it was crucial for candidates to be able to attract support from MPs whose first choice had dropped out of the race: the winner needed the parliamentary equivalent of sloppy seconds. As Table 4.1 shows, this was exactly what Hague was able to do. After the first round, his vote went up by twenty-one, compared to an increase of fifteen for Clarke, and eleven for Redwood. After the second, his 
vote went up by thirty, compared to just six for Clarke. At each stage, then, Hague's support went up by the largest amount.

Table 4.1 Changes in support between rounds, 1997

\begin{tabular}{lccccc}
\hline & Round 1 & Round 2 & Change & Round 3 & Change \\
\hline Hague & 41 & 62 & $(+21)$ & 92 & $(+30)$ \\
Clarke & 49 & 64 & $(+15)$ & 70 & $(+6)$ \\
Redwood & 27 & 38 & $(+11)$ & - & - \\
Lilley & 24 & - & - & - & - \\
Howard & 23 & - & - & - & - \\
\hline
\end{tabular}

Hague's inoffensiveness was confirmed by a survey, conducted before the 1997 election, of Conservative MPs and prospective candidates. ${ }^{13}$ It asked two key questions. Who would they like to see as party leader? And to whom would they object as party leader? Hague was the only candidate with a respectable level of support who attracted no hostility. Indeed, only one respondent objected to Hague - and that was only because he said that he did not know what Hague stood for.

This enabled Hague to take the leadership, but it also presented him with a problem, because it meant that he enjoyed little enthusiastic support from his parliamentary party. His initial support - those who backed him in the first round of the contest - was limited to a small group of MPs in the centre of the party. Just a quarter of his parliamentary party voted for him as first choice. Indeed, many of that 25 per cent would have preferred Portillo, had he been available. Much of Hague's later support, and even some of his initial support, came to him faute de mieux, because there was no one better. As a result, Hague's support was broad - being able to encompass large parts of the parliamentary party - but it was not deep. There was little or no ideological core to his support. There were few people in his parliamentary party who wanted Hague because of what he could deliver.

\section{The party's official stance}

Hague's frontbench team during the 1997 Parliament came to be criticised from outsiders for its right-of-centre leanings, a tendency exacerbated when, early on in his leadership, a handful of Europhile MPs resigned from it in protest at the party's shift in stance over the euro. But with such a small parliamentary party, Hague's room for manoeuvre was distinctly limited, and he had to make the most of what he had. Given that the balance of the parliamentary party had over the last few elections been shifting to the (Euro-sceptic) right, it would have been very difficult for him to have appointed anything other than a right-of-centre Shadow Cabinet and frontbench team. ${ }^{14}$ 
An entirely different criticism came from within the parliamentary party. The Conservative frontbench was criticised by some of its own backbenches for not being adversarial enough towards the government. Yet between 1997 and 2001, the Conservative frontbench opposed 41 per cent of the bills introduced by the government, making it one of the most adversarial oppositions of recent times. ${ }^{15}$ Even at the height of adversarial politics between 1979 and 1983, with the gulf between the two parties at its widest since the Second World War, the official opposition, then Labour, voted against just over a third of the Thatcher government's legislation at Second or Third Reading. ${ }^{16}$

To be sure, there was an initial reluctance on the part of the Tory frontbench to oppose most aspects of the government's constitutional reform agenda, especially those bills (involving Scotland, Wales and Northern Ireland) where referendums had been held in the countries concerned. But as the government's agenda moved away from constitutional reform and away from legislation outlined in its election manifesto, so the Conservative frontbench began to oppose a higher proportion of government legislation, reaching a peak of 48 per cent in the second session and 45 per cent in the third. Even on Northern Ireland, traditionally a topic for cross-party agreement, consensus began to break down from June 1998 onwards. Here, despite having supported the Second Reading of the Northern Ireland (Sentences) Bill, the Conservative frontbench opposed the Bill's Third Reading, because they argued that the government had failed to link the issue of prisoner release with the need for the IRA to begin weapons decommissioning. From then on, the Conservatives became more critical of the government's Northern Ireland policy, while remaining broadly supportive of the overall 'peace process'.

But the Conservative parliamentary party did not always act as one. Throughout the Parliament, small groups of Conservative MPs refused to do the bidding of their whips and voted against their party line (usually also voting against the government in the process when the Conservative frontbench advice was to support the government or abstain). In addition to sporadic issue-based rebellions by backbench MPs, there was also a small ginger group of Conservative MPs - dubbed the 'awkward squad' - who set out to cause trouble for the government by throwing as many procedural spanners in the parliamentary works as possible, often against the advice of their own frontbench, and whose activities escalated as the Parliament progressed.

\section{Conservative backbench dissent}

The behaviour of Conservative MPs between 1997 and 2001 was almost the mirror image of that of Labour MPs in the same period. Whereas Labour 
MPs rebelled infrequently but in quantity, Conservative MPs rebelled more frequently but - with the exception of some very large rebellions at the beginning of the Parliament over devolution - usually in small numbers. ${ }^{17}$

In total, there were 163 occasions when Conservative MPs voted against the advice of their party whips during the Parliament, sixty-seven more than Labour. And although the awkward squad's activities (see below) account for a sizable proportion of that number, there were still 111 rebellions even once we discount their activities. Even without the activities of the awkward squad, therefore, Conservative MPs voted against their party line more times than did Labour MPs. The average size of these rebellions, though, was small (just six MPs), becoming smaller as the Parliament progressed: from eight in the first session to seven in the second, to six in the third, down to five in the final session. And whereas only a minority of Labour MPs broke ranks - albeit a minority that was larger than most people realised - the Conservative backbench rebellions involved some 128 Conservative MPs, just over three-quarters of the parliamentary party, and almost everyone who was a Conservative backbencher at some point in the Parliament.

The largest rebellion came at the beginning of the Parliament. With the Conservative frontbench largely acquiescent over the issue, the majority of Conservative backbench dissent during the first year of the Parliament came from Tory MPs unhappy about the government's proposals for devolution. Five consecutive votes in June 1997 saw an average of thirty-five Conservative backbenchers oppose the Referendums (Scotland and Wales) Bill, establishing the rules of the devolution referendums. The first and largest occurred over the issue of who should be allowed to vote. An amendment by Bill Cash proposed that the Scottish referendum should encompass the whole of the United Kingdom rather than merely those resident in Scotland. Some eighty-two Conservative backbenchers, a full half of the parliamentary party, backed the amendment. Four other rebellions saw twenty, thirty-seven, twenty-two and nine Conservative MPs defy their whips, a total of ninetyfour doing so at some point during the Bill's passage. ${ }^{18}$

The other issues to provoke rebellion amongst Conservative MPs ranged widely, but one was largely absent and one was dominant. The absentee was Europe. Despite being the major faultline during the Major leadership, there were remarkably few backbench revolts over Europe (none of them sizeable) under Hague's leadership. The dominant issue was Northern Ireland. It provoked forty separate Conservative rebellions. Again, these tended to be small, averaging just five MPs, but as the parliament progressed, so the number of Conservative MPs prepared to break ranks over the issue grew, and their cumulative impact was considerable, involving fifty-one different MPs, almost a third of the parliamentary party. Backbench unhappiness with the government's policy towards Northern Ireland (and, concomitantly, with their frontbench's stance towards the government) ran deep on the 
Conservative benches and may at least help to explain the Tory frontbench shift on the issue in 1998.

The largest rebellion came over the Third Reading of the Northern Ireland Bill (the Anglo-Irish plan to revive the 'peace process'), when sixteen Tory MPs voted against the Bill, in defiance of the frontbench line to abstain; but the most concerted spell of opposition came over the Disqualifications Bill. The Bill dealt with the anomaly created by the Northern Ireland Act 1998 that permitted a member of the Irish Senate to be a member of the Northern Ireland Assembly but not of any other UK legislature. It ended the prohibition against members of the Irish legislature - both the Dail and the Senate - from being a member of any legislature in the United Kingdom, including the House of Commons, the Scottish Parliament, the Welsh Assembly and the Northern Ireland Assembly. The Conservative frontbench stance was to abstain. ${ }^{19}$ Many Conservative MPs disagreed. Andrew Hunter spoke for many of his colleagues on the Conservative benches when he described the Bill as just the latest obscene landmark in a process that ostensibly began as a peace process, but long ago became, in reality, a sordid, shabby process of appeasement'. ${ }^{20}$ The government had hoped to get through the remaining stages of the Bill the following day. But a group of Conservative MPs began a marathon session of filibustering, and the deliberations of the Committee of the Whole House ran from 5.43p.m. on 25 January 2000 to 7.19a.m. the following day. As a result, a full day's business, including Prime Minister's Questions, was lost. ${ }^{21}$ Five separate divisions throughout the night and into the following morning saw an average of eleven Conservatives support amendments and block government motions that attempted to hasten the Bill's passage, with a total of thrity-three Conservative MPs voting against their frontbench position at some point.

The most prominent Conservative dissenter on Northern Ireland was Andrew Hunter who cast twenty-six dissenting votes on that issue alone. But because precedence in the debates is given to MPs from Northern Irish parties, even a vociferous opponent of the government's policies like Hunter was restricted to relatively few speeches and interventions, and the Conservative divisions on the issue therefore went largely unnoticed outside of Westminster.

\section{The 'awkward squad'}

As well as these ad hoc rebellions by Conservative MPs, the Government also faced concerted opposition from a small ginger group of Conservative MPs. Whereas many Labour rebels did not like the labels given them by the media, many members of this group of Conservative MPs, formed around two former ministers, Eric Forth and David Maclean, revelled in their description as 'the awkward squad'. They engaged in a parliamentary form of guerrilla warfare, 
with both their behaviour and their raison d'être likened by one of the group to that of the French resistance during the Second World War:

When France was invaded it was finished. Then two and a half thousand out of 40 million joined the Maquis. We can't defeat the Government in votes, we can't defeat them in argument, since no one ever listens, but we can tie them down in the same way that the Maquis tied down the Germans ... it's only pot shots, but it's a form of opposition. ${ }^{22}$

It would be carrying the military analogy too far to suggest that they saw their frontbench as quislings or like the leaders of Vichy France, but many members of the awkward squad certainly thought that their High Command was too conciliatory and too consensual towards the government - that Conservative frontbenchers did not have 'the stomach for it'. Singled out for criticism were the Chief Whip, James Arbuthnot, and the Shadow Leader of the House for most of the period, Sir George Young, both of whom many awkward squad members regarded as 'grandees'. 'Some of them learned their politics with cucumber sandwiches.' These grandees wanted to play by the rules, accepting the norms of the House and saw anything else as infra dig. Eric Forth and his colleagues, by contrast, saw themselves as parliamentary Clint Eastwoods, playing by their own rules. One described himself as 'a parliamentary yob': 'It's in my nature to play party politics rough.' Collectively, their aim was to cause what one of them called 'buggeration', 'to make life for the government as miserable as possible'. In some cases, this grew from a neo-liberal ideological objection to the idea of all but the most minimal of legislation ('What I want is institutional gridlock. I want it to be nearly impossible for government to do anything'). But it was just as likely to result from a belief in the value of confrontational politics, in which the point of opposition was to oppose, and the role of the backbencher was to hold the government to account. If the Conservative frontbench would not oppose the government, then Conservative backbenchers would have to do it.

Despite the label, there was no formal organisation behind the awkward squad and its membership was both amorphous and variable. The inner core was essentially just four Conservative MPs. Eric Forth and David Maclean organised most of the group's various activities, Forth acting as the unofficial whip, with Gerald Howarth and David Wilshire never far behind. There were no formal meetings, although the core of the awkward squad were all members of the Thatcherite 'No Turning Back' Group which met for dinner once a month, where they would all 'have a good whinge' about the activities of their own frontbench and 'wish they were opposing things'. Around the inner core was an outer core, which comprised some twelve MPs, who were regularly to be found acting in concert with the inner core but who were less involved in organising their activities. And there was then another group of MPs, again around twelve in number, who would occasionally join in 
(especially once their activities escalated later in the Parliament), but whose involvement was less regular and depended at least in part on the particular issues involved and the tactics being employed. As one said: 'Only the psychotic care enough to stay up all night.'

Initially, Forth and Maclean began by blocking Private Members' Bills, something that the procedures of the Commons makes relatively easy to do. ${ }^{23}$ They believed that the government was abusing private members' time by getting backbench MPs to introduce so-called 'handout' bills, government bills in all but name. ${ }^{24}$ By blocking Private Members' Bills, therefore, Forth and Maclean aimed to force the bill to be reintroduced later, which would eat up government time. ${ }^{25}$ But they also shared an ideological objection to private members' legislation in general, believing that they were badly scrutinised, usually originated with single-issue groups, and nearly always imposed regulations and costs. In their view, it was possible to have 'good' Private Members' Bills, but they had to be totally non-controversial, consisting of just a few clauses. In practice 'precious few' were like this.

As the Parliament progressed, so the awkward squad's activities increased, both in terms of frequency and in terms of the number of MPs involved. The slow start was partly due to the effects of the defeat of 1997 - a process that one MP described as 'getting over the shell shock'. But Conservative MPs also had to adapt to being in opposition, to adjust to the realities of being on the outside, and to discover the more obscure parliamentary procedures with which they could obstruct government business. Once they discovered them, and once they had tasted blood, they realised that causing trouble for the government was 'fun'. It 'gives me a purpose in life', said one, 'gets me up perkier in the morning. It's worth it to see their faces.'

By the third session, the group had begun to object to otherwise noncontentious bills, and to call divisions and filibuster during their passage. At times, the awkward squad's activities were in clear contravention of the Conservative whips. This was especially true of the Disqualifications Bill, where the Conservative frontbench had hoped to embarrass the Prime Minister on his 1000th day in office at Prime Minister's Questions. ${ }^{26}$ However, more often than not, the votes occurred late at night when the Conservative whips' line was that their MPs could go home, and very often there was no Conservative line to be rebelling against. The inner core would instead stay around, looking for a fight, forcing divisions, often on otherwise noncontentious statutory instruments. Each division takes between twelve and fifteen minutes, itself wasteful of government MPs' time, but more importantly the prospect of an unexpected division forces the government whips to keep enough MPs in the precincts of the Commons to ensure victory, inconveniencing Labour MPs for hours more than the time taken for the votes themselves. As Austin Mitchell noted in The House Magazine's Commons Diary: 'I'd thought 10p.m. was now a guaranteed P.O.H. (Push Off 
Home) time ... Not so. Tonight 200 'volunteers' are kept back until 2.30 to vote down six of Forth's Freedom Fighters.' ${ }^{27}$ Even more frustrating for Labour MPs were those occasions when Conservative backbenchers would keep a debate going into the early hours of the morning, only, at some ungodly hour, for the Tories not to force a vote.

Perhaps because some of them secretly admired the awkward squad's activities (and perhaps because they could not do much to stop them even if they wanted to), the Conservative whips frequently turned a blind eye, even when the group's activities were in contravention of the party's whip, and no disciplinary action was taken against any of its members. Several members of the awkward squad admitted that if their whips had ever asked them to desist, they probably would have done so. But this attitude did not apply to the inner core. When a Tory whip tried to stop Forth filibustering during the Disqualifications Bill, he was given short shrift: 'Do you really think I've been here for eighteen hours and I've got the chance of losing a day's business and I'm going to give it up now? Piss off.'

By the beginning of the fourth session, the awkward squad's activities had escalated yet further, with them forcing divisions on the principle of a full quarter of the government's legislation, almost as much as the Conservative frontbench objected to. The introduction (as part of the process of 'modernisation' of the Commons) of deferred divisions, something that all Conservative MPs had voted against when they had been proposed (routinely describing them as an 'abomination'), made things even worse. 'Deferred divisions' did exactly what it said on the tin, with some divisions being deferred until the following week, when instead of walking through the division lobbies to record their votes, MPs handed in a ballot sheet between 3.30 and 5p.m., recording their votes on each division. The very first vote using a deferred division - on European Union fish quotas - saw the Conservative Party formally instruct its MPs to spoil their ballot papers by voting twice, an act that provoked a reprimand from the Speaker. ${ }^{28}$ And from then on, many deferred divisions saw small 'rebellions' by Conservative MPs. These were as much protests against the system - forcing votes on otherwise uncontroversial issues in order to slow down the process - as revolts over the issues themselves.

If the aim of the awkward squad was to annoy Labour MPs, then they certainly succeeded. Their activities infuriated many Labour backbenchers. Some, especially those first elected in 1997, were annoyed at what they saw as the 'futility of parliamentary games'. ${ }^{29}$ As one tired and frustrated MP complained in 2000: 'Here till four the other night, 250 of us, just for 20 Tories.' But Labour annoyance just made the Conservatives more determined. As one Conservative MP said, '[There is] nothing like seeing them rattled to make me want to do it again.' And just as Labour MPs disapproved of the activities of the Conservatives, so the Conservatives disdained the approach 
of some of the Labour MPs, especially the new ones. Labour MPs, one claimed, disliked 'anything that made their personal life awkward'. Another was more blunt. The New Labour MPs just wanted the rules of the Commons changed 'so that they can go home and change nappies. They think that they are here just to further the project, they see Parliament as an inconvenience, they just want to do what the Master wants.'

Yet amongst some Labour MPs there was grudging admiration for Forth and his colleagues. Some longer-serving Labour MPs, especially the more rebellious, knew that they would have done the same in opposition. During the 1970 Parliament a similar ginger group of Labour backbenchers had been set up by James Wellbeloved, which aimed, amongst other things, to knock a bit of stuffing out of the Government backbenchers'. ${ }^{30}$ During the early 1980s, when the PLP was falling apart in organisational terms and MPs were beset by reselection battles, two opposition MPs, Dennis Skinner and Bob Cryer, similarly took the fight to the Conservative government by opposing legislation late into the night, prompting one experienced Labour backbencher to describe Forth as 'Dennis Skinner in drag'. A former Labour Chief Whip ('with a Ph.D. in opposition') confessed that he frequently colluded with the activities of his backbenchers. 'There were many times when I did not have complete control over my backbenchers. There were even more times when I pretended not to have control over them and colluded with them in frustrating the government of the day.' ${ }^{31}$ Nor did all Labour MPs object to late nights: 'I worked nights in a steel factory, so if the Tories want to play silly buggers, I'll work nights again.' The sneaking respect for Forth was shown when he was voted 'Opposition Politician of the Year' in the Channel 4 and The House Magazine awards in 1999. The opposition to him, though, was equally clear when his name was put up for the House of Commons Commission to succeed Sir Peter Lloyd, and - after a heated debate - he was voted off. ${ }^{32}$

One of the effects of the awkward squad's activities was to increase the pressure on the Labour frontbench to pursue yet further 'modernisation' of the Commons. The resentment their activities caused on the Labour benches was at least partly responsible for the decision to introduce deferred divisions and the programming of almost all government bills in November 2000. ${ }^{33}$ One Labour whip, Graham Allen, thought that 'by his antics over the past year or so', Forth had 'done more for the modernisation of this place than serious-minded reformers like myself managed in fourteen years or more'. ${ }^{34}$ This compounded Conservative feelings that the government was progressively taking away the rights of opposition backbench MPs properly to scrutinise the government, so by the beginning of 2001 what one awkward squad member called a 'destructive cycle' had developed: 'They [the government] antagonised us, we retaliated by using loopholes, so they closed the loopholes, which antagonised us.' 
Near the end of the Parliament one Conservative MP reflected that, for all their effort, the awkward squad seemed to have achieved little. No minister has had a heart attack yet', he said ruefully. ${ }^{35}$ Another thought that they had achieved 'no immediate tangible result ... all we've done is keep people up late'. But that was all most of them had wanted to do. They had not been aiming to defeat the enemy, just to take 'pot shots' at it and to cause 'buggeration'. And in that, they had been successful.

\section{Plus ça change ...}

The general election of 2001 will not be remembered for any dramatic changes in the composition of the Commons. ${ }^{36}$ A total of 560 sitting MPs were re-elected. Just twenty-one were defeated. Eighty-five per cent of the House was therefore exactly the same after the election as it had been before - the lowest turnover since 1945. ${ }^{37}$ The turnover on the Conservative benches was slightly higher (there were thirty-three new Conservative MPs, although seven of these were 'retreads', former MPs returning to the Commons), but the overall number of Conservatives rose by just one. Indeed, given that one of the Conservative gains was Tatton - a seat held by the Independent MP Martin Bell since 1997, but in which Bell was not standing in 2001 - the net Conservative gain from other political parties was effectively nil.

Just as four years before, their first task was the choosing of a new leader. William Hague's reforms may have ended the parliamentary party's monopoly in leadership selection, but the parliamentarians remained extremely important, far more so than in other British political parties. The new rules involved the party's wider membership in the country (see Chapter 5), but only once the incumbent leader has resigned (that is, they give party members no say over ejecting an incumbent) and the wider membership are merely offered a choice between the two candidates most favoured by the parliamentary party. ${ }^{38}$

Also as in 1997, five candidates stood for the leadership in 2001: Kenneth Clarke, Iain Duncan Smith, Michael Portillo, Michael Ancram and David Davis. A multiple ballot system was used to choose the final two candidates to go through to the ballot of the party membership, with the bottom placed candidate being eliminated after each round.

Unfortunately the first round saw two candidates, Davis and Ancram, share the wooden spoon, leading to the vote being held for a second time. The party's rules were widely criticised for not foreseeing such a possibility ('Can't they get anything right?' asked the Daily Mail; 'Chaos', said the Sun), with surprisingly little criticism focusing on the two candidates themselves for failing to withdraw from the race in the interests of the party. The re-run contest, two days later, saw both Davis and Ancram lose votes, whilst the front three candidates improved their positions slightly. Ancram was then 
eliminated from the contest; Davis withdrew (albeit after initially attempting to stay in the running). ${ }^{39}$ Both urged their supporters to vote for Duncan Smith.

The second round proper saw Clarke top the poll (fifty-nine votes), followed by Duncan Smith (fifty-four). Portillo - who had been in front in the first two rounds, and who was widely seen as the frontrunner - came third by one vote and was therefore eliminated.

Table 4.2 Changes in support between rounds, 2001

\begin{tabular}{lccccc}
\hline & Round 1 & $\begin{array}{c}\text { Round 1 } \\
\text { (re-run) }\end{array}$ & Change & Round 2 & Change \\
\hline Clarke & 36 & 39 & $(+3)$ & 59 & $(+20)$ \\
Duncan Smith & 39 & 42 & $(+3)$ & 54 & $(+12)$ \\
Portillo & 49 & 50 & $(+1)$ & 53 & $(+3)$ \\
Davis & 21 & 18 & $(-3)$ & - & - \\
Ancram & 21 & 17 & $(-4)$ & - & - \\
\hline
\end{tabular}

There were clear ideological divisions between the candidates' supporters. 'All five candidates drew their principal support from their natural ideological constituencies.' ${ }^{40}$ Clarke's support came predominantly from the party's wets, but also - because he was perceived by some to be an electoral asset - from the party faithful, those MPs who put the party interest ahead of their own ideological preferences. ${ }^{41}$ Duncan Smith and Davis were both Thatcherites, and drew most of their support from that ideological group, with Davis attracting the backing of the awkward squad. Ancram, who put himself forward as the compromise candidate, drew his support largely from the party faithful. Portillo's support was perhaps the broadest of all. He drew support from neo-liberals (his own brand of Conservatism), but also from some 'damps' (wet versions of the party's wets) and from some of the party faithful. He also enjoyed the support of the majority of the Shadow Cabinet.

Yet despite this broad support, and despite being widely seen as a shoo-in, he failed to capture enough support to get through to the ballot of the membership. Portillo's problem was easily summed up. Unlike Hague (in 1997), or both Clarke and Duncan Smith (in 2001), Portillo was unable to attract supporters from defeated candidates. As Table 4.2 shows, after the first round his support went up by just one vote (compared to three each for Clarke and Duncan Smith). In the second round - when Clarke's support went up by twenty and Duncan Smith's by twelve - Portillo's support went up by just three, and not enough to keep him in the race. He was almost no MP's second choice. Indeed, there was a sizeable group of Conservative MPs who wanted to stop Portillo at any cost. ${ }^{42}$ Portillo himself summed his problem up well: 'I seem to unite people against me in antagonism.' ${ }^{43}$

The sources of this antagonism were various. Portillo suffered from 
accusations that he (or, more often, his aides, supporters and assorted hangers-on) had been disloyal to Hague (and, prior to 1997, Major). Such accusations appeared repeatedly during the campaign - as with Ann Widdecombe's complaints about 'back-biting' or Amanda Platell's video diary - but these were merely the public manifestations of widespread ill-feeling amongst parts of the parliamentary party. ${ }^{44}$ He also suffered both from a sense amongst some MPs that he had shifted his beliefs (apparently abandoning Thatcherism, to the chagrin of those who had kept the faith) and, just as importantly, that there was still no clear sign of exactly what his new beliefs were. As one journalist put it to him when he addressed the parliamentary Press Gallery on the day of the second ballot: 'Are you still on a journey or are you just refuelling?'. ${ }^{45}$ In the event, he was going nowhere.

Under the new rules, the Conservative parliamentary party may no longer be kingmakers, but they are still gatekeepers. The gate was closed on Ancram, Davis and Portillo, but allowed Clarke and Duncan Smith through. George Jones in the Daily Telegraph claimed that 'the party faces the most fundamental choice over its future since Margaret Thatcher became leader twenty-six years ago'. ${ }^{46}$ But that fundamental final choice was no longer the parliamentary party's.

\section{Notes}

1 This chapter draws on research funded by the Leverhulme Trust, and reported in Philip Cowley, Revolts and Rebellions: Parliamentary Voting Under Blair (London, Politico's, 2002). The authors are very grateful to all the MPs who helped with the research.

2 By 1993 a mere 19 per cent of the electorate considered the Conservatives to be united. This figure fell into single figures for parts of 1996. Not since polls asked the question in the early 1970 s has the party been so widely regarded as split', wrote Ivor Crewe in 1996. I. Crewe, '1979-1996', in A. Seldon (ed.), How Tory Governments Fall (London, Fontana, 1996), p. 432.

3 P. Riddell, 'Tories have yet to face up to their new status', The Times, 9 October 1997.

4 A. Seldon, Major. A Political Life (London, Weidenfeld \& Nicolson, 1997), p. 3; P. Webster, 'Major vents anger at rebels', The Times, 8 October 1997.

5 T. Blair, speech to the Parliamentary Labour Party, Church House, London, 7 May 1997.

6 The death of Sir Michael Shersby, MP for Uxbridge, soon after polling day, meant that by the time the Parliament resumed the Conservatives were reduced to just 164 MPs.

7 A. Roth and B. Criddle, New MPs of 1997 and Retreads (London, Parliamentary Profiles Services Ltd, 1997), p. i.

8 B. Criddle, 'MPs and Candidates', in D. Butler and D. Kavanagh, The British General Election of 1997 (London, Macmillan, 1997), p. 202. In the 2001 volume, D. Butler and D. Kavanagh, The British General Election of 2001 (London, Palgrave, 2002) erroneously claim that the figure was eleven (p. 39). Things may have been bad, but they were not that bad. 
9 For more details on the changes in the method of selecting the Leader see K. Alderman, 'Revision of leadership election procedures in the Conservative Party', Parliamentary Affairs 52:2 (1999) 260-74. More generally, see J. Lees-Marshment and S. Quayle, 'Empowering the members or marketing the party? The Conservative reforms of 1998', Political Quarterly, 72:2 (2001) 204-12; R. Kelly 'Democratising the Tory Party', Talking Politics, 11:1 (1998) 28-33; and P. Cowley and S. Quayle, 'The Conservatives: running on the spot', in A. Geddes and J. Tonge (eds), Labour's Second Landslide (Manchester, Manchester University Press, 2002), pp. 47-64.

10 G. Brandreth, Breaking the Code (London, Weidenfeld \& Nicolson, 1999), p. 472.

11 See, for example, P. Cowley and M. Bailey, 'Peasants' uprising or religious war: re-examining the 1975 Conservative leadership contest', British Journal of Political Science, 30:4 (2000) 599-629; P. Cowley and J. Garry, 'The British Conservative Party and Europe: the choosing of John Major', British Journal of Political Science, 28:3 (1998) 473-99.

12 See P. Cowley, 'Just William? A supplementary analysis of the 1997 Conservative leadership contest', Talking Politics, 10:2 (1997/98) 91-5, for full details of the analysis.

13 Cowley, 'Just William', pp. 91-2.

14 See, for example, the data in P. Norris, 'Anatomy of a Labour landslide', in P. Norris (ed.), Britain Votes 1997 (Oxford, Oxford University Press, 1997), Table 7, p. 529.

15 See P. Cowley, Revolts and Rebellions: Parliamentary Voting Under Blair (London, Politico's, 2002), Table 10.1.

16 D. Van Mechelen and R. Rose, Patterns of Parliamentary Legislation (Aldershot, Gower, 1986). More generally, see R. Rose, Do Parties Make A Difference? (London, Macmillan, 1980).

17 Compare Cowley, Revolts and Rebellions, Chs 5 and 10.

18 The first session also saw a sizeable rebellion over the Criminal Justice (Terrorism and Conspiracy) Bill. In the second largest Conservative rebellion of the Parliament, forty Conservative MPs joined the sixteen Labour backbenchers who objected to all the Bill's stages being completed in one day.

19 The Conservatives were concerned about the release of paramilitary prisoners in the absence of decommissioning. So, although they abstained on the Bill's Second Reading, they put forward and supported Ulster Unionist amendments during the Bill's Committee stage that insisted that the Bill should not take effect until there had been substantial and verifiable decommissioning.

20 HC Debs, 24 January 2000, col. 66 .

21 It was the first time since 14 June 1988 that a sitting of the House had wrecked the next day's sitting. Then MPs sat from 2.30p.m. on Tuesdays until 8.01p.m. on Wednesday as they deliberated the Housing Bill. The House Magazine, 31 January 2000.

22 All unattributed quotations in this chapter are drawn from interviews with Conservative (or, occasionally, Labour) MPs in the 1997 Parliament. Simon Hoggart drew a similar comparison: 'They are like guerrillas fighting in the forests and hills, the rag-taggle remains of a defeated army', 'Ragged remains of defeated Tory army fight on', Guardian, 20 March 2001.

23 See H. Marsh and D. Marsh, 'Tories in the killing fields', Journal of Legislative Studies, forthcoming.

24. They were - but then so has every government in recent years. See D. Marsh and M. Read, Private Members' Bills (Cambridge, Cambridge University Press, 1988).

25 As happened with, for example, the Fur Farming Bill, when Forth and Maclean divided the House three times in March and May 1999. As well as talking out many 
bills, Forth (and usually Maclean) often divided the House. In the first session, they divided the House on the Fireworks Bill, in the second, the Animal Welfare (Prohibition of Imports) Bill, in the third, the Warm Homes and Energy Conservation Bill, the Age Equality Commission Bill, and, in the fourth, the Outworking Bill, the Christmas Day (Trading) Bill and even the High Hedges Bill!

26 M. White, 'Rebels ruin day 1000 showdown', Guardian, 27 January 2000.

27 The House Magazine, 15 January 2001. A Labour whip similarly described the awkward squad as the 'provisional wing of the Tory party'. HC Debs, 28 June 2001, col. 833.

28 Even here, though, there were some dissenters. Two MPs voted with the Government, while five voted against the Government.

29 Or, as Quentin Letts put it following Forth's elevation to Shadow Leader of the House following Iain Duncan Smith's election as Conservative leader: “'Go, Forth, and multiply" is what most Labour MPs think of the new Shadow Leader of the House.' Q. Letts, 'HM Opposition: a user's guide', New Statesman, 22 October 2001, p. 35.

30 P. Norton, Dissension in the House of Commons, 1945-74 (London, Macmillan, 1975), p. 389.

31 HC Debs, 28 June 2001, col. 825.

32 HC Debs, 2 February 2000, cols. 1175-6. He was, though, almost immediately put back on to the Commission, only to have to resign his place when he became Shadow Leader of the House after the 2001 Election.

33 See P. Norton, 'Parliament', in A. Seldon (ed.), The Blair Effect (London, Little, Brown \& Company, 2001), p. 51.

34 HC Debs, 28 June 2001, col. 834. One long-serving Labour MP agreed: 'Forth played into the hands of those, particularly the women, who said: 'If we can't change the hours now, we never will.'

35 This might have been a joke. But perhaps not.

36 For more on the composition of the Commons post-2001, see P. Cowley, 'The Commons: Mr Blair's lapdog?', in P. Norris (ed.), Britain Votes 2001 (Oxford, Oxford University Press, 2001), pp. 251-64.

37 That is, excluding the two short Parliaments of 1950-51 and February-October 1974 .

38 Indeed, there is no compulsion on the parliamentary party to put two candidates forward to the members at the final stage.

39 See, for example, the leader column, 'Down to three please', Daily Telegraph, 13 July 2001.

40 P. Norton, 'The Conservative leadership election', British Politics Group Newsletter, 106 (2001), p. 12.

41 The various ideological categories are explained in P. Norton, “"The lady's not for turning": but what about the rest? Margaret Thatcher and the Conservative Party', Parliamentary Affairs, 43:1 (1990) 41-58. For their continuing viability, see P. Cowley and P. Norton, 'What a ridiculous thing to say! (which is why we didn't say it): a response to Timothy Heppell', British Journal of Politics and International Relations, 4:2 (2002) 325-9; and P. Norton 'The Conservative Party: is there anyone out there?', in A. King (ed.), Britain at the Polls 2001 (Chatham NJ, Chatham House, 2002), pp. 85-8.

42 Indeed, the size of Clarke's final lead - which surprised Clarke himself - was at least partly due to a handful of Duncan Smith supporters who, thinking that Duncan Smith was himself going to top the poll, decided to vote for Clarke in order to block Portillo. 
Too clever by half, their actions almost had disastrous consequences for their candidate.

43 Simon Walters, Tory Wars (London, Politico's, 2001), p. 207.

44 By far the best single account is Walters, Tory Wars.

45 Walters, Tory Wars, p. 212. Norton, 'The Conservative leadership election', discusses the extent to which Portillo had (and had not) shifted in his ideological beliefs.

46 G. Jones, 'The choice is Europe or Thatcherism', Daily Telegraph, 18 July 2001. 